\title{
Effect of Bulky Manures and Fermented Liquid Organics on Growth, Yield, Nutrient Uptake and Economics of French Bean (Phaseolus vulgaris L) Under Rainfed Condition
}

\author{
Gowthamchand, N.J. ${ }^{1}$, Ganapathi ${ }^{1 *}$ and Soumya, T.M. ${ }^{2}$
}

${ }^{1}$ Department of Soil Science and Agricultural Chemistry, College of Agriculture, University of Agricultural and Horticultural Sciences, Shivamogga, Karnataka, India

${ }^{2}$ Department of Agronomy, College of Agriculture, University of Agricultural and Horticultural Sciences, Shivamogga, Karnataka, India

*Corresponding author: fsiruvakki@gmail.com (ORCID ID: 0000-0003-4554-4231)

Paper No. 816

Received: 21-09-2019

Revised: $19-01-2020$

Accepted: 27-02-2020

\begin{abstract}
A field experiment was conducted to study the "Effect of bulky organic manures and fermented liquid organics on growth, yield, nutrient uptake and economics of French bean (Phaseolus vulgaris L) under rainfed condition" at Organic Farming Research Centre, Zonal Agricultural and Horticultural Research Station (ZAHRS), Navile, Shivamogga, during Kharif 2018-19. The experiment was laid out in randomized block design with ten treatments comprising of different bulky organic manures (FYM and Vermicompost) and fermented liquid organic manures (Beejamrutha, Jeevamruta, Panchagavya and Cow urine) were replicated thrice. Experimental results revealed that, significantly higher growth, yield attributes, economics and nutrient uptake with good shelf-life and protein content of the French bean were found in the treatment which received Beejamrutha (seed treatment) + Jeevamrutha (soil application @ $\left.500 \mathrm{~L} \mathrm{ha}^{-1}\right)+100 \%$ RDN through vermicompost + Foliar spray of Panchagavya @ 3\% ( $\left.\mathrm{T}_{6}\right)$ and were on par with application of Beejamrutha (seed treatment) + Jeevamrutha (soil application @ $500 \mathrm{~L} \mathrm{ha}^{-1}$ ) +50\% RDN through FYM + 50\% RDN through vermicompost + Foliar spray of Panchagavya @ 3\% $\left(\mathrm{T}_{7}\right)$ and Beejamrutha (seed treatment) + Jeevamrutha (soil application @ $500 \mathrm{~L} \mathrm{ha}^{-1}$ ) + 100\% RDN through FYM + Foliar spray of Panchagavya @ 3\% $\left(\mathrm{T}_{5}\right)$. Simillar trend of higher benefit cost ratio was also recorded in the same set of treatment combination. This study indicated that combined application of bulky and fermented liquid organic manures in seed treatments, soil application and foliar spray performed better in organic French bean production at best benefit ratio cost.
\end{abstract}

\section{Highlights}

0 French bean pod yield was influenced by combined application of bulky and fermented liquid organics.

- Foliar spray of fermented liquid organics greatly influenced the growth and yield attributes of French bean.

Keywords: Liquid organic manure, Pod yield, Haulm yield, Benefit cost ratio

French bean (Phaseolus vulgaris L.) is one of the most important leguminous vegetable crop in India. It is also known as common bean or kidney bean. French bean is grown extensively because of its short duration and nutritive value. It is a good source of protein, calcium, phosphorus, iron, carotene, thiamine, riboflavin and vitamin $\mathrm{A}$ and $\mathrm{C}$.
In India, it is grown for tender vegetables, shelled green beans and dry beans. French bean is grown in different parts of world occupying an area of $1.57 \mathrm{~m}$ ha with total production of $24.22 \mathrm{~m} \mathrm{t}$. In India it is cultivated in an area of 2,41,652 ha with a production of 6,75,188 t (Anon., 2017). In Karnataka, it is grown on an area of 15,699 ha with the total 
production of 16,785 tonnes and productivity of $11 \mathrm{t} \mathrm{ha}^{-1}$ (Anon., 2017). However, it is grown under rainfed as well as irrigated conditions. The excess and indiscriminate use of chemicals in vegetable production decreases the quality of the produce, soil fertility and pollutes the environment. Substitution of chemicals by the organic means is very important for sustainable agriculture production to improve the quality of produce, maintenance of soil fertility and health of environment. Low productivity of French bean attributed to low fertility and soil organic matter content due to inadequate supply of organic materials. Apart from this deterioration of soil health is due to intensive use of chemicals in agriculture. Maintenance of the soil health is the pre requisite for sustainable agriculture. Organic farming is one in which maintain soil health and quality of produce. Organic manuring of farm land is an age old traditional practice evolved by our fore fathers wherein only organic manures or natural inputs available on the farm were used to reduce the cost of production against chemical inputs. Organic agriculture is a production system that sustains the soil health, ecosystems and people. It relies on ecological processes, biodiversity and cycles adapted to local conditions, rather than the use of inputs with adverse effects. It has been estimated that the soil organic carbon content in India has drastically reduced from 1.2 per cent in 1970's to 0.60 per cent in 2000 (Devsenapathy 2008) and declining further. Use of organics in crop production is gaining much popularity. It helps to enhance and maintain soil organic carbon status for sustained crop yield and also India blessed with rich natural heritage of soil, climate and biodiversity has a vast potential for organic farming (Debashis Dash and Amardeep 2018).

Combined application of bulky organic manures along with liquid organic manures like panchagavya, beejamrutha, jeevamrutha, and cow urine etc., is a more synchronized system and can release the nutrients as per the need of crop to sustain higher productivity (Shwetha and Babalad 2008). There was no systemic research was carried out in this aspects in French bean production, keeping these points in view, the present investigation was undertaken to know the effect of combination of different organic manures on growth, yield and cost of production of French bean under rainfed condition.

\section{MATERIALS AND METHODS}

Field experiment were conducted on french bean at Organic Farming Research Centre, Zonal Agricultural and Horticultural Research Station (ZAHRS), Navile, Shivamogga, during Kharif 2018-19. The soil of experimental site belongs to taxonomic class of Typic Haplustalf with sandy loam texture. Composite soil sample was collected from the experimental site before the imposition of treatments, processed and analyzed for physical, chemical and biological characteristics of soil. The results of analysis indicated that the soil was acidic with a $\mathrm{pH}$ of 5.93 , electrical conductivity of 0.076 $\mathrm{dS} \mathrm{m}^{-1}$ and recorded low organic carbon content $\left(4.1 \mathrm{~g} \mathrm{~kg}^{-1}\right)$. The soil was low in available nitrogen $\left(283.00 \mathrm{~kg} \mathrm{ha}^{-1}\right)$, high in available $\mathrm{P}_{2} \mathrm{O}_{5}(93.21 \mathrm{~kg}$ $\left.\mathrm{ha}^{-1}\right)$ and medium in available $\mathrm{K}_{2} \mathrm{O}\left(165.98 \mathrm{~kg} \mathrm{ha}^{-1}\right)$. The exchangeable $\mathrm{Ca}$ and $\mathrm{Mg}$ were 3.74 and 1.91 $\mathrm{cmol}(\mathrm{p}+) \mathrm{kg}^{-1}$, available sulphur was $16.75 \mathrm{mg} \mathrm{kg}^{-1}$ and all the DTPA extractable micronutrients were above the critical limits (Fe-29.96, Mn-9.24, Zn-0.73 and $\left.\mathrm{Cu}-0.78 \mathrm{mg} \mathrm{kg}^{-1}\right)$. The experiment was laid out in randomized block design with ten treatments of bulky organic manures and fermented liquid organic manures comprising as $\mathrm{T}_{1}$ : Beejamrutha (seed treatment) + Jeevamruta (soil application), $\mathrm{T}_{2}$ : $\mathrm{T}_{1}+100 \%$ RDN through FYM, $\mathrm{T}_{3}: \mathrm{T}_{1}+100 \%$ RDN through Vermicompost, $\mathrm{T}_{4}: \mathrm{T}_{1}+50 \%$ RDN through FYM $+50 \%$ RDN through Vermicompost, $\mathrm{T}_{5}: \mathrm{T}_{2}$ + Foliar spray of 3\% Panchagavya, $\mathrm{T}_{6}: \mathrm{T}_{3}+$ Foliar spray of $3 \%$ Panchagavya, $\mathrm{T}_{7}: \mathrm{T}_{4}+$ Foliar spray of $3 \%$ Panchagavya, $\mathrm{T}_{8}: \mathrm{T}_{2}+$ Foliar spray of $10 \%$ Cow urine, $\mathrm{T}_{9}: \mathrm{T}_{3}+$ Foliar spray of $10 \%$ Cow urine, $\mathrm{T}_{10}: \mathrm{T}_{4}+$ Foliar spray of $10 \%$ Cow urine and were replicated thrice. The two foliar spray of fermented liquid organics were taken at vegetative and foliar stages of French bean crop. Nutrient concentrations of fermented liquid organic formulations used in experiment were given in Table 1 . The healthy seeds of French bean variety Arka sharath were dipped in Beejamruta solution for one minute and then seeds were dried in the shade and were sown on with a recommended seed rate of $40 \mathrm{~kg}$ per hectare. The seeds required for each plot as per the spacing in the crop were calculated, furrows were opened at a row spacing of $45 \mathrm{~cm}$ with the help of wooden marker and seed to seed $15 \mathrm{~cm}$ distance was maintained. The seeds were dibbled at 3 to $5 \mathrm{~cm}$ depth and later covered with soil. Growth 
and yield parameters, pods quality were recorded and analysed by standard methods. The data were analysed by standard statistical methods.

Table 1: Nutrient status of fermented liquid organic formulations used in the experiment

\begin{tabular}{lllll}
\hline $\begin{array}{l}\text { Chemical } \\
\text { properties }\end{array}$ & $\begin{array}{l}\text { Beejam- Jeevam- } \\
\text { rutha }\end{array}$ & $\begin{array}{l}\text { Panchaga- } \\
\text { rutha }\end{array}$ & $\begin{array}{l}\text { Cow } \\
\text { vyrine }\end{array}$ \\
\hline $\mathrm{pH}$ & 8.11 & 5.02 & 5.6 & 7.98 \\
$\mathrm{EC}\left(\mathrm{dS} \mathrm{m}^{-1}\right)$ & 1.96 & 3.64 & 4.12 & 0.89 \\
$\begin{array}{l}\text { Total Nitrogen (\%) } \\
\text { Total Phosphorus } \\
(\%)\end{array}$ & 0.29 & 1.81 & 1.79 & 1.70 \\
$\begin{array}{l}\text { Total Potassium } \\
(\%)\end{array}$ & 0.52 & 0.190 & 0.098 & 0.134 \\
$\begin{array}{l}\text { Total Zinc (mg } \\
\left.\mathrm{kg}^{-1}\right)\end{array}$ & 1.8 & 1.36 & 0.49 & 1.12 \\
$\begin{array}{l}\text { Total Copper }(\mathrm{mg} \\
\left.\mathrm{kg}^{-1}\right)\end{array}$ & 3.3 & 4.51 & 0.38 & 0.17 \\
$\begin{array}{l}\text { Total Iron (mg kg } \\
\text { Total Manganese } \\
\left(\mathrm{mg} \mathrm{kg}^{-1}\right)\end{array}$ & 17.86 & 36.83 & 20.71 & 3.83 \\
\hline
\end{tabular}

\section{RESULTS AND DISCUSSION}

\section{Growth parameters of French bean crop}

The data pertaining to growth parameters are presented in Table 2. Application of different organic manures along with the combination of fermented liquid organics had significant influence on plant height and number of branches per plant at different growth stages of crop. Increase in plant height and number of branches per plant over the treatment which received Beejamrutha (seed treatment) + Jeevamruta (soil application @ $\left.500 \mathrm{~L} \mathrm{ha}^{-1}\right)\left(\mathrm{T}_{1}\right)$ alone at 30, 45 DAS and at harvest. Similar trend of significant increase in dry matter accumulation per plant at 40 DAS and at harvest. This might be attributed to application of different organic manures with their differential nutrient composition were in turn increased the availability of nutrients in soil at later stages of the crop growth. Among different treatments, significantly higher plant height, number of branches per plant and dry matter acuulation per plant was recorded with application of Beejamrutha (seed treatment) + Jeevamrutha (soil application @ $500 \mathrm{~L} \mathrm{ha}^{-1}$ ) + $100 \%$ RDN through vermicompost + Foliar spray of Panchagavya @ 3\% ( $\left.\mathrm{T}_{6}\right)$ at all the growth stages of crop. This was attributed to panchagavya, a potential source to play great role for promoting growth and providing immunity in plant system besides, a source of nutrients and microorganisms. Bio-chemical properties of panchagavya revealed that it possesses almost all the major nutrients like $\mathrm{N}, \mathrm{P}, \mathrm{K}$ and micronutrients necessary for plant and growth hormones like IAA and GA required for crop growth (Selvaraj et al. 2007). Similarly, Aashutosh et al. (2019) reported gradual increase in doses of vermicompost for 0 to 10.0 ton ha ${ }^{-1}$ significantly improved plant growth, flowering and yield attributing traits along with higher availability of NPK in post harvested soil.

The significant improvement in the accumulation of dry matter in plant was attributed to increased supply of plant nutrients, chlorophyll synthesis, nitrogen metabolism and phytohormones with the application of Panchagavya. Apart from nutrient supply, Panchagavya was a proven biofertilizers, viz., Azospirillium, Azotobacter, Phosphobacter, Pseudomonas that play an important role in stimulation of plant growth by secreting IAA and GA (Sanjutha et al. 2008). Several other workers reported that Panchagavya was an efficient biostimulant that enhances the physiological growth of the plant and Jeevamrutha promotes immense biological activity in soil and enhance availability of essential nutrients to crop as reported by (Nileema et al. 2011). Babalad (1999) reported that application of vermcompost @ $2.5 \mathrm{t} \mathrm{ha}^{-1}$ to soybean significantly enhanced the plant height, number of branches per plant and total dry matter etc. compared to the treatment which received Beejamrutha (seed treatment) + Jeevamrutha (soil application @ 5001 ha $\left.^{-1}\right)\left(\mathrm{T}_{1}\right)$ alone.

\section{Yield and yield parameters of French bean crop}

The yield attributing parameters such as number of pods per plant, pod length $(\mathrm{cm})$, pod weight $(\mathrm{g}$ plant $\left.^{-1}\right)$, pod yield and haulm yield $\left(\mathrm{t} \mathrm{ha}^{-1}\right)$ were significantly influenced by addition of organic manures in combination with different fermented organic liquid formulations are presented in Table 3.

At harvest, among various treatments, significantly higher green pod yield (16.43 $\left.\mathrm{t} \mathrm{ha}^{-1}\right)$, haulm yield (2.82 $\mathrm{t} \mathrm{ha}^{-1}$ ) and yield components viz., green pod number per plant (24.12), green pod length per plant $(15.52 \mathrm{~cm})$, green pod weight per plant (193.57 g) were recorded with application of Beejamrutha (seed treatment) + Jeevamrutha (soil application 
Table 2: Effect of organic manures and fermented liquid organic formulations on French bean growth attributes at different growth stages

\begin{tabular}{|c|c|c|c|c|c|c|c|c|c|c|c|}
\hline \multirow{3}{*}{ Treatments combinations } & \multicolumn{4}{|c|}{ Plant height $(\mathrm{cm})$} & \multicolumn{4}{|c|}{$\begin{array}{c}\text { Number of branches per } \\
\text { plant }\end{array}$} & \multicolumn{3}{|c|}{$\begin{array}{c}\text { Dry matter accumulation } \\
\left(\text { g plant }^{-1}\right)\end{array}$} \\
\hline & \multicolumn{4}{|c|}{ DAS } & \multicolumn{4}{|c|}{ DAS } & \multicolumn{3}{|c|}{ DAS } \\
\hline & 15 & 30 & 45 & Harvest & 15 & 30 & 45 & Harvest & 20 & 45 & Harvest \\
\hline $\begin{array}{l}\mathrm{T}_{1} \text { : Beejamrutha (seed treatment) } \\
\text { + Jeevamrutha (soil application) }\end{array}$ & 13.34 & 21.27 & 24.61 & 26.27 & 1.00 & 2.18 & 3.57 & 3.94 & 2.38 & 3.98 & 9.72 \\
\hline $\mathrm{T}_{2}: \mathrm{T}_{1}+100 \%$ RDN through FYM & 14.06 & 25.31 & 35.11 & 36.45 & 1.00 & 2.95 & 3.90 & 4.79 & 2.42 & 5.38 & 14.13 \\
\hline $\begin{array}{l}\mathrm{T}_{3}: \mathrm{T}_{1}+100 \% \mathrm{RDN} \text { through } \\
\text { Vermicompost }\end{array}$ & 15.59 & 30.30 & 37.73 & 38.73 & 1.00 & 3.46 & 4.13 & 4.95 & 3.08 & 5.69 & 14.82 \\
\hline $\begin{array}{l}\mathrm{T}_{4}: \mathrm{T}_{1}+50 \% \text { RDN through FYM } \\
+50 \% \text { RDN through Vermicompost }\end{array}$ & 14.92 & 27.69 & 36.86 & 37.53 & 1.00 & 3.25 & 4.01 & 4.90 & 2.51 & 5.54 & 14.47 \\
\hline $\begin{array}{l}\mathrm{T}_{5}: \mathrm{T}_{2}+\text { Foliar spray of } 3 \% \\
\text { Panchagavya }\end{array}$ & 14.03 & 26.01 & 39.88 & 41.85 & 1.00 & 2.98 & 4.67 & 5.86 & 2.53 & 8.14 & 17.23 \\
\hline $\begin{array}{l}\mathrm{T}_{6}: \mathrm{T}_{3}+\text { Foliar spray of } 3 \% \\
\text { Panchagavya }\end{array}$ & 15.71 & 31.60 & 42.56 & 45.89 & 1.21 & 3.68 & 5.35 & 6.43 & 3.17 & 9.78 & 18.68 \\
\hline $\begin{array}{l}\mathrm{T}_{7}: \mathrm{T}_{4}+\text { Foliar spray of } 3 \% \\
\text { Panchagavya }\end{array}$ & 14.93 & 28.17 & 40.16 & 43.49 & 1.00 & 3.29 & 4.85 & 6.00 & 2.75 & 8.71 & 17.89 \\
\hline $\begin{array}{l}\mathrm{T}_{8}: \mathrm{T}_{2}+\text { Foliar spray of } 10 \% \text { Cow } \\
\text { urine }\end{array}$ & 14.05 & 25.61 & 37.53 & 38.87 & 1.00 & 3.09 & 4.26 & 4.91 & 2.35 & 6.85 & 16.36 \\
\hline $\begin{array}{l}\mathrm{T}_{9}: \mathrm{T}_{3}+\text { Foliar spray of } 10 \% \text { Cow } \\
\text { urine }\end{array}$ & 15.56 & 30.68 & 38.43 & 40.90 & 1.18 & 3.57 & 4.35 & 5.41 & 2.94 & 7.51 & 17.05 \\
\hline $\begin{array}{l}\mathrm{T}_{10}: \mathrm{T}_{4}+\text { Foliar spray of } 10 \% \text { Cow } \\
\text { urine }\end{array}$ & 15.03 & 28.23 & 37.70 & 39.70 & 1.00 & 3.19 & 4.25 & 5.27 & 2.67 & 6.95 & 16.64 \\
\hline S. Em \pm & 0.803 & 1.059 & 1.313 & 1.382 & 0.06 & 0.122 & 0.225 & 0.232 & 0.26 & 0.54 & 0.478 \\
\hline C.D. at 5\% & NS & 3.148 & 3.902 & 4.107 & NS & 0.362 & 0.668 & 0.689 & NS & 1.06 & 1.46 \\
\hline
\end{tabular}

Note: RDN: Recommended dose of nitrogen, DAS: Days after sowing,FYM: Farm Yard Manure.

Table 3: Effect of organic manures and fermented liquid organic formulations on yield and yield parameters of French bean crop

\begin{tabular}{|c|c|c|c|c|c|}
\hline Treatments combinations & $\begin{array}{l}\text { No. of pods } \\
\text { per plant }\end{array}$ & $\begin{array}{l}\text { Average pod } \\
\text { length }(\mathrm{cm})\end{array}$ & $\begin{array}{l}\text { Pod weight } \\
\text { per plant }(g)\end{array}$ & $\begin{array}{l}\text { Green pod } \\
\text { yield }\left(t \mathrm{ha}^{-1}\right)\end{array}$ & $\begin{array}{l}\text { Haulm } \\
\text { yield }\left(t \text { ha }^{-1}\right)\end{array}$ \\
\hline $\begin{array}{l}\mathrm{T}_{1} \text { : Beejamrutha (seed treatment) + Jeevamrutha } \\
\text { (soil application) }\end{array}$ & 12.67 & 10.98 & 98.31 & 8.07 & 1.76 \\
\hline $\mathrm{T}_{2}: \mathrm{T}_{1}+100 \%$ RDN through FYM & 17.14 & 13.07 & 139.57 & 13.11 & 2.02 \\
\hline $\mathrm{T}_{3}: \mathrm{T}_{1}+100 \% \mathrm{RDN}$ through Vermicompost & 18.02 & 13.48 & 149.72 & 13.56 & 2.13 \\
\hline $\begin{array}{l}\mathrm{T}_{4}: \mathrm{T}_{1}+50 \% \text { RDN through FYM }+50 \% \text { RDN } \\
\text { through Vermicompost }\end{array}$ & 17.24 & 13.29 & 142.95 & 13.15 & 2.05 \\
\hline $\mathrm{T}_{5}: \mathrm{T}_{2}+$ Foliar spray of $3 \%$ Panchagavya & 21.53 & 14.91 & 171.48 & 15.42 & 2.60 \\
\hline $\mathrm{T}_{6}: \mathrm{T}_{3}+$ Foliar spray of $3 \%$ Panchagavya & 24.22 & 15.52 & 193.57 & 16.43 & 2.82 \\
\hline $\mathrm{T}_{7}: \mathrm{T}_{4}+$ Foliar spray of $3 \%$ Panchagavya & 22.12 & 15.21 & 175.25 & 15.81 & 2.75 \\
\hline $\mathrm{T}_{8}: \mathrm{T}_{2}+$ Foliar spray of $10 \%$ Cow urine & 18.63 & 13.72 & 158.02 & 13.93 & 2.21 \\
\hline $\mathrm{T}_{9}: \mathrm{T}_{3}+$ Foliar spray of $10 \%$ Cow urine & 20.17 & 14.01 & 166.62 & 14.78 & 2.38 \\
\hline $\mathrm{T}_{10}: \mathrm{T}_{4}+$ Foliar spray of $10 \%$ Cow urine & 19.23 & 13.94 & 161.10 & 14.41 & 2.34 \\
\hline S. Em \pm & 1.03 & 0.49 & 7.72 & 0.48 & 0.08 \\
\hline C.D. at $5 \%$ & 3.06 & 1.46 & 22.94 & 1.43 & 0.24 \\
\hline
\end{tabular}

Note: RDN: Recommended dose of nitrogen, FYM: Farm Yard Manure. 
@ $\left.500 \mathrm{~L} \mathrm{ha}^{-1}\right)+100 \%$ RDN through vermicompost + Foliar spray of Panchagavya@ @ $\%\left(\mathrm{~T}_{6}\right)$. This might be due to favourable effect of combination of fermented liquid organics and Vermicompost in increase the nutrients availability and microbial population and Panchagavya foliar spray promote the vegetative growth viz., number of branches per plant and reproductive growth. These findings are in the line with those reported by Somasundaram et al. (2003b); Somasundaram et al. (2007). and Devakumar et al. (2014).

Jeevamrutha contains enormous amount of microbial load which enhances the microbial activity in soil upon its application, while panchagavya act as a source of nutrients besides producing hormonal effect. These results are also in conformity with the findings of Shwetha and Babalad (2008), who found higher seed yield of soybean in combined application of organic manures along with fermented organics viz., beejamrutha, jeevamrutha soil application and panchagavya spray. Several workers have also reported that application of organic liquid formulations along with organic manures might have helped faster decomposition and better release of required nutrients and helps to increase yield and yield components. These results are in line with findings of Deshmukh et al. (2012) who reported that application of $100 \%$ RDN through vermicompost + jeevamrutha resulted in higher grain and straw yield of soybean. Lower yield and yield components of french bean were recorded in treatment $\left(\mathrm{T}_{1}\right)$ which received only Beejamrutha (seed treatment) + Jeevamrutha (soil application @ $500 \mathrm{~L} \mathrm{ha}^{-1}$ ). This was due to reduced availability of nutrients for normal growth and development of crop.

\section{Nutrient uptake by French bean crop}

Green pod, haulm and total uptake of nitrogen, phosphorus and potassium by French bean crop were significantly higher due to the application of organic manure along with liquid organics over the treatment which received Beejamrutha (seed treatment) + Jeevamrutha (soil application @ 500 $\left.\mathrm{L} \mathrm{ha}^{-1}\right)\left(\mathrm{T}_{1}\right)$ alone (Table 4$)$. Among the various combination of organic treatments significantly higher pod, haulm and total uptake of nitrogen, phosphorus and potassium were recorded in the treatment which received Beejamrutha (seed treatment) + Jeevamrutha (soil application @ 500 L $\left.\mathrm{ha}^{-1}\right)+100 \%$ RDN through vermicompost + Foliar spray of Panchagavya @ $3 \%\left(\mathrm{~T}_{6}\right)$ and it was on par with application of Beejamrutha (seed treatment) + Jeevamrutha (soil application @ $500 \mathrm{~L} \mathrm{ha}^{-1}$ ) + 50 per cent RDN through FYM + 50 \% RDN through

Table 4: Effect of organic manures and fermented liquid organic formulations on total NPK uptake by French bean crop at harvest

\begin{tabular}{|c|c|c|c|c|c|c|c|c|c|}
\hline \multirow{2}{*}{ Treatments combinations } & \multicolumn{3}{|c|}{ Nitrogen } & \multicolumn{3}{|c|}{$\begin{array}{c}\text { Phosphorus } \\
\left.\text { Uptake (kg ha }{ }^{-1}\right)\end{array}$} & \multicolumn{3}{|c|}{ Potassium } \\
\hline & $\begin{array}{l}\text { Green } \\
\text { pod }\end{array}$ & Haulm & $\begin{array}{l}\text { Total } \\
\text { uptake }\end{array}$ & $\begin{array}{l}\text { Green } \\
\text { pod }\end{array}$ & Haulm & $\begin{array}{l}\text { Total } \\
\text { uptake }\end{array}$ & $\begin{array}{l}\text { Green } \\
\text { pod }\end{array}$ & Haulm & $\begin{array}{l}\text { Total } \\
\text { uptake }\end{array}$ \\
\hline $\begin{array}{l}\mathrm{T}_{1} \text { : Beejamrutha (seed treatment) } \\
\text { + Jeevamrutha (soil application) }\end{array}$ & 29.00 & 11.92 & 40.92 & 4.41 & 1.43 & 5.84 & 19.40 & 16.18 & 35.57 \\
\hline $\mathrm{T}_{2}: \mathrm{T}_{1}+100 \% \mathrm{RDN}$ through FYM & 40.67 & 15.86 & 56.53 & 5.96 & 2.00 & 7.95 & 27.85 & 21.76 & 49.61 \\
\hline $\mathrm{T}_{3}: \mathrm{T}_{1}+100 \% \mathrm{RDN}$ through Vermicompost & 42.30 & 16.90 & 59.20 & 6.57 & 2.21 & 8.77 & 28.86 & 23.16 & 52.02 \\
\hline $\begin{array}{l}\mathrm{T}_{4}: \mathrm{T}_{1}+50 \% \text { RDN through } \mathrm{FYM}+50 \% \mathrm{RDN} \\
\text { through Vermicompost }\end{array}$ & 41.53 & 16.33 & 57.86 & 6.16 & 2.08 & 8.24 & 28.18 & 22.53 & 50.71 \\
\hline $\mathrm{T}_{5}: \mathrm{T}_{2}+$ Foliar spray of $3 \%$ Panchagavya & 52.76 & 23.81 & 76.57 & 9.28 & 2.93 & 12.21 & 37.11 & 29.58 & 66.68 \\
\hline $\mathrm{T}_{6}: \mathrm{T}_{3}+$ Foliar spray of $3 \%$ Panchagavya & 59.00 & 27.87 & 86.87 & 10.81 & 3.51 & 14.32 & 42.32 & 33.61 & 75.93 \\
\hline $\mathrm{T}_{7}: \mathrm{T}_{4}+$ Foliar spray of $3 \%$ Panchagavya & 55.88 & 24.85 & 80.73 & 9.81 & 3.10 & 12.91 & 38.94 & 30.74 & 69.68 \\
\hline $\mathrm{T}_{8}: \mathrm{T}_{2}+$ Foliar spray of $10 \%$ Cow urine & 45.83 & 19.95 & 65.78 & 7.07 & 2.51 & 9.58 & 30.90 & 26.21 & 57.12 \\
\hline $\mathrm{T}_{9}: \mathrm{T}_{3}+$ Foliar spray of $10 \%$ Cow urine & 50.02 & 22.14 & 72.15 & 8.34 & 2.84 & 11.18 & 34.46 & 28.53 & 62.99 \\
\hline $\mathrm{T}_{10}: \mathrm{T}_{4}+$ Foliar spray of $10 \%$ Cow urine & 47.95 & 20.98 & 68.93 & 7.59 & 2.70 & 10.28 & 32.78 & 27.18 & 59.96 \\
\hline S. Em \pm & 2.68 & 1.41 & 4.26 & 0.51 & 0.20 & 0.72 & 2.04 & 1.51 & 3.94 \\
\hline C. D. at $5 \%$ & 8.12 & 4.25 & 12.82 & 1.54 & 0.61 & 2.18 & 6.21 & 4.56 & 11.86 \\
\hline
\end{tabular}

Note: RDN: Recommended dose of nitrogen, FYM: Farm Yard Manure. 
vermicompost + Foliar spray of Panchagavya @ 3\% $\left(\mathrm{T}_{7}\right)$ and Beejamrutha (seed treatment) + Jeevamrutha (soil application @ $500 \mathrm{~L} \mathrm{ha}^{-1}$ ) + 100\% RDN through FYM + Foliar spray of Panchagavya @ 3\% $\left(\mathrm{T}_{5}\right)$. This might be explained based on more growth always accomplished with more uptake and retentivity of various nutrients. Hence, yield maximization on the other hand includes all the processes associated with uptake of nutrients, translocation, partitioning, assimilation and mobilization of nutrients at different growth stages of crop (Divyashree et al. 2018)

Mineralization of organic source in addition to soil had provided ample opportunity for plants to uptake these elements in addition to fixation that normally takes place. Vermicompost, farm yard manure and jeevamrutha application reduced the loss of nutrients through leaching and made available to plant which created a balancing effect on supply of nitrogen, phosphorus and potassium. These results are in support with the findings of Vijayapriya et al. (2005) and Arunkumar and Srinivasa (2018). Beaulah (2002) and Kumawat et al. (2009) reported that Panchagavya which provide more macro and micronutrients as well as growth regulators like auxins and GA which helped in producing higher bio mass and also in better recovery of $\mathrm{N}, \mathrm{P}, \mathrm{K}, \mathrm{S}, \mathrm{Zn}$ and $\mathrm{Fe}$ in plant.

\section{Quality parameters of French bean pods}

Application of organic manure combined with different fermented liquid organics improved the protein content and keeping quality over the treatment which received Beejamrutha (seed treatment) + Jeevamrutha (soil application @ $\left.500 \mathrm{~L} \mathrm{ha}^{-1}\right)\left(\mathrm{T}_{1}\right)$ alone (Table 5). Among various treatments studied significantly higher protein and more number of shelf life days was recorded with application of Beejamrutha (seed treatment) + Jeevamrutha (soil application@ 500 L ha $^{-1}$ ) + $100 \%$ RDN through vermicompost + Foliar spray of Panchagavya @ 3\% followed by application of Beejamrutha (seed treatment) + Jeevamrutha (soil application@ $0500 \mathrm{~L} \mathrm{ha}^{-1}$ ) + 50\% RDN through FYM + $50 \%$ RDN through vermicompost + Foliar spray of Panchagavya @ 3\% and Beejamrutha (seed treatment) + Jeevamrutha (soil application @ $500 \mathrm{~L}$ ha $\left.^{-1}\right)+100 \%$ RDN through FYM + Foliar spray of Panchagavya @ 3\%. Less number of shelf-life days and protein content was recorded with application of Beejamrutha (seed treatment) + Jeevamrutha (soil application@ $500 \mathrm{~L} \mathrm{ha}^{-1}$ ) alone. Increase in protein content and keeping quality of French bean might be due to application of vermicompost and other different organic liquid formulations. Similar findings were also observed by Jayaram Reddy and Reddy (2011); Siddaram (2012); Maheshbabu et al. (2008).

Table 5: Effect of organic manures and fermented liquid organic formulations on protein content and shelf life of French bean pods

\begin{tabular}{|c|c|c|}
\hline Treatments combinations & $\begin{array}{l}\text { Crude } \\
\text { protein }(\%)\end{array}$ & $\begin{array}{l}\text { Shelf-life } \\
\text { (days) }\end{array}$ \\
\hline $\begin{array}{l}\mathrm{T}_{1} \text { : Beejamrutha (seed treatment) } \\
+ \text { Jeevamrutha (soil application) }\end{array}$ & 9.44 & 5.41 \\
\hline $\mathrm{T}_{2}: \mathrm{T}_{1}+100 \%$ RDN through FYM & 10.31 & 6.95 \\
\hline $\begin{array}{l}\mathrm{T}_{3}: \mathrm{T}_{1}+100 \% \text { RDN through } \\
\text { Vermicompost }\end{array}$ & 10.63 & 7.28 \\
\hline $\begin{array}{l}\mathrm{T}_{4}: \mathrm{T}_{1}+50 \% \text { RDN through } \\
\mathrm{FYM}+50 \% \text { RDN through } \\
\text { Vermicompost }\end{array}$ & 10.50 & 7.00 \\
\hline $\begin{array}{l}\mathrm{T}_{5}: \mathrm{T}_{2}+\text { Foliar spray of } 3 \% \\
\text { Panchagavya }\end{array}$ & 11.38 & 8.96 \\
\hline $\begin{array}{l}\mathrm{T}_{6}: \mathrm{T}_{3}+\text { Foliar spray of } 3 \% \\
\text { Panchagavya }\end{array}$ & 11.94 & 9.85 \\
\hline $\begin{array}{l}\mathrm{T}_{7}: \mathrm{T}_{4}+\text { Foliar spray of } 3 \% \\
\text { Panchagavya }\end{array}$ & 11.75 & 9.41 \\
\hline $\begin{array}{l}\mathrm{T}_{8}: \mathrm{T}_{2}+\text { Foliar spray of } 10 \% \text { Cow } \\
\text { urine }\end{array}$ & 10.94 & 7.64 \\
\hline $\begin{array}{l}\mathrm{T}_{9}: \mathrm{T}_{3}+\text { Foliar spray of } 10 \% \text { Cow } \\
\text { urine }\end{array}$ & 11.25 & 8.35 \\
\hline $\begin{array}{l}\mathrm{T}_{10}: \mathrm{T}_{4}+\text { Foliar spray of } 10 \% \text { Cow } \\
\text { urine }\end{array}$ & 11.06 & 8.01 \\
\hline S. Em \pm & 0.59 & 1.25 \\
\hline C. D. at $5 \%$ & 0.18 & 0.41 \\
\hline
\end{tabular}

Note: RDN: Recommended dose of nitrogen, FYM: Farm Yard Manure.

\section{Economics of French bean crop production}

Higher cost of cultivation ( $₹ 47,656.00)$, gross return (₹ 24,6450.00) and net return (₹ 19,8794.00) were recorded with application of Beejamrutha (seed treatment) + Jeevamrutha (soil application @ 500 L ha $\left.^{-1}\right)+100 \%$ RDN through vermicompost + Foliar spray of Panchagavya @ 3\% followed by application of Beejamrutha (seed treatment) + Jeevamrutha (soil application@ $900 \mathrm{~L} \mathrm{ha}^{-1}$ ) + 100\% RDN through vermicompost + Foliar spray of Cow urine @ 10\% 
Table 6: Effect of organic manures and fermented liquid organic formulations on economics of French bean production

\begin{tabular}{|c|c|c|c|c|}
\hline Treatments combinations & $\begin{array}{l}\text { Cost of cultivation } \\
\left(₹ \mathrm{ha}^{-1}\right)\end{array}$ & $\begin{array}{l}\text { Gross return } \\
\left(₹ \mathrm{ha}^{-1}\right)\end{array}$ & $\begin{array}{l}\text { Net return } \\
\left(₹ h^{-1}\right)\end{array}$ & B:C \\
\hline $\mathrm{T}_{1}$ : Beejamrutha (seed treatment) + Jeevamrutha (soil application) & 27775.00 & 121050.000 & 93275.00 & 3.36 \\
\hline $\mathrm{T}_{2}: \mathrm{T}_{1}+100 \%$ RDN through FYM & 43337.50 & 196650.000 & 153312.50 & 3.54 \\
\hline $\mathrm{T}_{3}: \mathrm{T} 1+100 \%$ RDN through Vermicompost & 46456.00 & 203400.00 & 156944.00 & 3.38 \\
\hline $\mathrm{T}_{4}: \mathrm{T} 1+50 \%$ RDN through FYM $+50 \%$ RDN through Vermicompost & 44896.75 & 197250.00 & 152353.25 & 3.39 \\
\hline $\mathrm{T}_{5}: \mathrm{T} 2+$ Foliar spray of $3 \%$ Panchagavya & 44537.50 & 231300.00 & 186762.50 & 4.19 \\
\hline $\mathrm{T}_{6}: \mathrm{T} 3+$ Foliar spray of $3 \%$ Panchagavya & 47656.00 & 246450.00 & 198794.00 & 4.17 \\
\hline $\mathrm{T}_{7}: \mathrm{T} 4+$ Foliar spray of $3 \%$ Panchagavya & 46096.75 & 237150.00 & 191053.25 & 4.14 \\
\hline $\mathrm{T}_{8}: \mathrm{T} 2+$ Foliar spray of $10 \%$ Cow urine & 44337.50 & 208950.00 & 165612.50 & 3.82 \\
\hline $\mathrm{T}_{9}: \mathrm{T} 3+$ Foliar spray of $10 \%$ Cow urine & 47456.00 & 221700.00 & 175244.00 & 3.77 \\
\hline $\mathrm{T}_{10}: \mathrm{T} 4+$ Foliar spray of $10 \%$ Cow urine & 45896.75 & 216150.00 & 171253.25 & 3.81 \\
\hline
\end{tabular}

Note: cost of FYM: 1300 per tonne, Cost of vermicompost: ₹ 4 per $\mathrm{kg}$, Market price of $1 \mathrm{~kg}$ fresh pod: ₹ 17, B: C: Benefit: Cost ratio.

(Table 6). Lower cost of cultivation, gross return and net return were recorded with application of Beejamrutha (seed treatment) + Jeevamrutha (soil application@ $500 \mathrm{~L} \mathrm{ha}^{-1}$ ). But higher B:C (4.19) was observed with application of Beejamrutha (seed treatment) + Jeevamrutha (soil application @ 500 L $\left.\mathrm{ha}^{-1}\right)+50 \%$ RDN through FYM + 50\% RDN through vermicompost + Panchagavya @ 3\% foliar spray compared other treatments. This might be attributed to easily availability and low cost of FYM over the vermicmpost. Further, it was noticed that combined application of organic manures with fermented liquid organics had higher benefit cost ratio over the treatment which received only organic manure or liquid organics. These results are in conformity with the findings of Shwetha and Babalad (2008) and Harika et al. (2019).

Based on the results, the experimental findings have significant practical utility in the field of vegetables cultivation under organic farming. Use of Beejamrutha as a seed treatment, Jeevamrutha as a soil application and 100 per cent recommended dose of nitrogen supplying through vermicompost with foliar spray of Panchagavya @ 3 per cent recorded higher growth, green pod yield, quality, shelf life and nutrient uptake of French bean with highest benefit cost ratio as compared to alone applications. Panchagavya is an efficient bio stimulant that enhances the physiological growth of the plant and jeevamrutha promotes immense biological activity in soil and enhance availability of essential nutrients by faster decomposition of vermicompost to crop.

\section{REFERENCES}

Aashutosh, Mukesh Kumar, Sunil Malik, Manoj Kumar Singh, Singh, S.P., Veena Chaudhary and sharma,V.R. 2019. Optimization of spacing, doses of vermicompost and foliar appication of salicylic acid on growth, flowering and soil health of Chrysanthemum (Dendranthema grandiflora Tzvelev) CV. "Guldasta” International Journal of Agriculture, Environment and Biotechnology, 12(3): 213-224.

Anonymous, 2017. Horticultural Crop Statistics of Karnataka State at a Glance. Government of Karnataka, Lalbagh, Bangalore.

Anonymous, 2017. Statistics Division, Food and Agriculture Organization of the United Nations. Rome, Italy.

Arunkumar, B.R. and Srinivasa, N. 2018. Effect of Gypsum and Borax Application on Yield, Nutrient Content and Uptake in Maize under Different Nutrient Management Practices. International Journal Pure and Applied Bioscience, 6(4): 181-189.

Babalad, H.B. 1999. Integrated nutrient management for sustainable production in soybean based cropping systems. Ph. D. Thesis, Univ. Agric. Sci., Dharwad, Karnataka (India).

Beaulah, A. 2002. Growth and development of moringa (Moringa oleifera L.) under organic and inorganic systems of culture. Ph.D. Thesis, Tamil Nadu Agri. Univ., Coimbatore, Tamil Nadu.

Debashis Dash and Amardeep. 2018. A Review on Organic Farming as a Potential Sector of Agripreneurship Development among the Tribal Youth of India. International Journal of Agriculture, Environment and Biotechnology, 11(5): 761-767.

Deshmukh, J.P., Potkile, S.N., Shingrup, P.V. and Patil, S.P. 2012. Effect of organic nutrient management on soybeanwheat crop sequence under irrigated condition. Extended Summaries Vol. 2: $3^{\text {rd }}$ Int. Agron. Congress, 549-550.

Devkumar, N., Shubha, S., Rao, G.G.E. and Imrankhan, 2014. Studies on soil fertility, cow urine and panchagavya levels 
on growth and yield of maize. Proceedings of the $4^{\text {th }}$ ISOFAR Scientific conference. 'Building Organic Bridges', at the Organic World Congress, 13-15 Oct., Istanbul, Turkey (eprint ID 23358)

Devsenapathy, 2008. Organic farming, In: CASA Training on Commercial Agriculture, conducted by TNAU during Jan-Feb.

Divyashree, U., Dinesh kumar, M. and Ganapathi, 2018. Effect of different fertilizer levels on nutrient uptakeand yield of little millet (Panicum sumatrense). International Journal of Science and Nature, 9 (2): 201-205.

Harika, J.V. Sagar Maitra, Tanmoy Shankar, Monisankar Bera and Pilli Manasa. 2019. Effect of integrated nutrient management on productivity, nutrient uptake and economics of Finger Millet (Eleusine coracana L. Gaertn). International Journal of Agriculture, Environment and Biotechnology, 12(3): 273-279.

Jayaram reddy, M. and Reddy, V.C. 2011. Developing organic package of practices for yield maximization of rainfed field bean. Annu. Rep. (2011-2012). Research Institute on Organic Farming, Univ. Agric. Sci., Bengaluru, Karnataka.

Kumawat, R.N, Mahajan, S.S., Mertia, R.S. 2009. Growth and development of Ground nut (Arachis hypogaea) under foliar application of panchagavya and leaf extracts of endemic plants. Indian Journal of Agronomy, 54(3): 324-331.

Maheshbabu, H.M., Ravi hunje, Biradar patil, N.K. and Babalad, H.B. 2008. Effect of organic manures on plant growth, seed yield and quality of Soybean. Karnataka Journal of Agricultural. Sciences, 21(2): 219-221.

Nileema, S., Gore and Sreenivasa, M.N. 2011. Influence of liquid organic manures on growth, nutrient content and yield of tomato (Lycopersicon esculentum L.) in the sterilized soil. Karnataka Journal of Agricultural Sciences, 24(2): 153-157.
Sanjutha, S., Subramanian, C., Indu rani and Maheswari, J. 2008. Integrated nutrient management in Andrographis paniculata. Research Journal of Agriculture and Biological Sciences, 4(2): 141- 145.

Selvaraj, J., Ramaraj, B., Devarajan, K., Seenivasan, N., Senthilkumar, S. and Sakthi, E. 2007. Effect of organic farming on growth and yield of thyme. Articles and Abstracts of Nation, pp. 13-14,

Shwetha, B.N. and Babalad, 2008. Effect of nutrient management through organics in soybean- wheat cropping system. M.Sc. (Agri.) Thesis, Univ. Agri. Sci., Dharwad, Karnataka.

Siddaram, 2012. Effect of farm yard manure and bio-digester liquid manure on the performance of aerobic rice- field bean cropping sequence. P.hD. Thesis, Univ. Agric. Sci., Bangalore, Karnataka, India.

Somasundaram, E., Mohamed, Amanullah, M., Thirukkumaran, K., Chandrasekaran., Vaiapuri, K., Sathyemoorthi, K. and Sthyamoorthi, K. 2007. Biochemical changes, Nitrogen flux and yield of crops due to organic sources of nutrients under maize based cropping system. Journal of Applied Science and Research, 3(12): 1724-1729.

Somasundaram, E., Sankaran, N., Meena, N., Thiyagarajan, T.M., Chandragiri, K.K. and Panneerselvam, S. 2003b. Response of green gram to varied concentrations of panchagavya (organic nutrition) foliar application. Madras Agricultural Journal, 90(1-3): 169-172.

Vijayapriya, M., Muthukkaruppan, S.M. and Ramachandra, S.M.V. 2005. Effect of sulphur and rhizobium inoculation on nutrient uptake by soybean ad soil fertility. Advances in Plant Science, 18(1): 19-21. 